\title{
Patch burning effects on grazing distribution
}

\author{
LANCE T. VERMEIRE, ROBERT B. MITCHELL, SAMUEL D. FUHLENDORF, AND ROBERT L. GILLEN
}

Authors are Rangeland Scientist, USDA-ARS, Fort Keogh Livestock and Range Research Laboratory, 243 Fort Keogh Rd., Miles City, Mont. 59301; Range Scientist, USDA-ARS, Wheat, Forage and Sorghum Unit, 344 Keim Hall, E.C., Univ. Nebr., Lincoln, Nebr. 68583; associate professor, Plant and Soil Sciences Department, Oklahoma State University, Stillwater, Okla. 74078-6028; and Range Scientist, USDA-ARS, 2000 18th Street, Woodward, Okla. 73801. At the time of the research, Vermeire and Mitchell were Research Assistant and Associate Professor, Department of Range, Wildlife, and Fisheries Management, Texas Tech University, Lubbock, Tex. 79409-2125.

\section{Abstract}

Post-fire forage growth is known to be a strong attractant for large herbivores. However, fire has generally been avoided as a grazing distribution tool for fear of localized over utilization of forage resources. Our objectives were to examine whether forage utilization was affected by season of burn, determine cattle grazing preference for burned sites relative to non-burned sites, determine forb response to patch burning, and describe the relationship between end-of-season standing crop and distance from burned sites. Sixteen, 4-ha plots were burned in mid-November or mid-April and left exposed to cattle grazing for the duration of the growing season. Burn treatments were blocked within pastures to allow individual herds access to fall-burned, springburned, and non-burned sites. Standing crop estimates for grasses, forbs, and total herbage were made in September by clipping on burned sites and at 50, 100, 200, 400 , and $800 \mathrm{~m}$ distant from the plot's edge. Standing crop was also sampled in exclosures on burned and non-burned sites. Cattle showed no preference for one burn season over the other. Cattle were strongly attracted to burned sites, reducing grass standing crop $78 \%$ within burns compared to $19 \%$ outside the influence of burns. Grass standing crop decreased in a predictable manner with proximity to burned plots. Forbs increased $60 \%$ to $1,095 \mathrm{~kg} \mathrm{ha}^{-1}$ on grazed burned plots, but were unaffected by distance from burns. Patch burning can be employed as an effective, inexpensive grazing distribution tool.

Key Words: animal behavior, fire, grazing management, mixed prairie, selection

The art and science of rangeland management often revolve around the issue of animal selectivity and its effects on the distribution of their resource utilization. Generally, scientists and managers have sought uniform animal distribution to avoid having areas of over-utilized and under-utilized forage resources. However, forage utilization is infrequently uniform because combinations of biotic and abiotic characteristics are rarely homogeneous across the landscape and herbivores naturally have preferences for site conditions conducive to their needs. Understanding many of these preferences, herbivore distribution has been altered

The authors wish to thank Eddie Wilson of the Oklahoma Department of Wildlife Conservation and Phil Sims of the Southern Plains Range Research Station for their hospitality and support.

Manuscript accepted 24 Jul. 03.

\section{Resumen}

Se sabe que el forraje que crece después de fuego es un fuerte atrayente para los grandes herbívoros. Sin embargo, el fuego generalmente ha sido evitado como una herramienta de distribución del apacentamiento por temor a provocar una sobreutilización localizada de los recursos forrajeros. Nuestros objetivos fueron examinar si la utilización del forraje fue afectada por la época de la quema, determinar la preferencia del ganado por los sitios quemados en relación a los sitios sin quemar, determinar la respuesta de las hierbas a la quema en parches y describir las relación entre la biomasa en pie al final de la estación y la distancia de los sitios quemados. 16 parcelas de 4 ha fueron quemadas a mediados de Noviembre o a mediados de Abril y quedaron expuestas al apacentamiento por el ganado durante la estación de crecimiento. Los tratamientos de quema fueron bloqueados dentro los potreros para permitir que hatos individuales tuvieran acceso a los sitios quemados en otoño, primavera y no quemados. En Septiembre, mediante corte, se hicieron estimaciones de la biomasa en pie de zacates, hierbas y del forraje total, las cuales se efectuaron en los sitios quemados y a 50, 100, 200, 400 y $800 \mathrm{~m}$ de distancia del limite de la parcelas quemada. La biomasa en pie también fue muestreada en exclusiones en los sitios quemados y sin quemar. El ganado no mostró preferencia por alguna de las épocas de quema, pero fue fuertemente atraído por los sitios quemados, reduciendo en $78 \%$ la biomasa en pie dentro de los sitios quemados comparado con una reducción del $\mathbf{1 9 \%}$ fuera del área de influencia de la quema. La biomasa en pie de los zacates disminuyó en una manera predecible con la proximidad de las parcelas quemadas. Las hierbas se incrementaron en $60 \%$ a $1,095 \mathrm{~kg} \mathrm{ha}^{-1}$ en las parcelas quemadas apacentadas, pero no fueron afectadas por la distancia a partir de la quema. La quema en parches puede ser empleada como herramienta efectiva y barata de distribución del apacentamiento.

with strategic placement of attractants such as water (Valentine 1947, Martin and Ward 1970), shade (McIlvain and Shoop 1971), nitrogen fertilizer (Hooper et al. 1969, Samuel et al. 1980), salt, and supplemental feeds (Martin and Ward 1973, Bailey and Welling 1999). Fencing and implementing specialized grazing systems also make animal distribution more uniform by limiting choices available to the animals (Vallentine 1990). However, slope and distance to water are still overriding factors controlling distribution of forage use (Bailey et al. 1996).

Fire is a powerful tool that can alter animal distribution at various scales. Grazing distribution is often more uniform on burned pastures because differences in forage nutritive value, palatabili- 
ty, and accessibility among patches are reduced. Given the choice of burned or non-burned sites, large herbivores strongly select burned sites as long as forage quantity is adequate (Mitchell and Villalobos 1999). Recommendations have therefore been made to use prescribed burning only on a management-unit basis. Wright (1974) suggested burned patches should be protected by fencing, or the remainder of the unit should be burned to prevent heavy localized grazing and overuse.

Such a view has prevented fire from being used to its potential as a distribution tool. If fire effects on distribution of forage use are strong and predictable, patch burning could effectively be used to increase the uniformity of forage use by attracting animals to generally underutilized areas, draw animals away from sensitive areas, or create greater landscape heterogeneity by encouraging concentrated forage use.

The objectives of this study were to examine whether forage utilization was affected by season of burn, determine cattle grazing preference for burned sites relative to non-burned sites, evaluate forb response to patch burning, and describe the relationship between end-of-season standing crop and distance from burned sites. We hypothesized that forage utilization would be greater on spring-burned plots than fall-burned plots because of expected changes in forage production and species composition, that forage utilization would be greater on burned sites than nonburned sites, that forb biomass would increase on and near burned sites, and end-of-season standing crop would decrease in a predictable manner with proximity to burned sites.

\section{Methods and Materials}

\section{Study Area}

The study was conducted in northwestern Oklahoma on the Hal and Fern Cooper Wildlife Management Area, about $15 \mathrm{~km}$ northwest of Woodward $\left(36^{\circ} 34^{\prime} \mathrm{N}, 99^{\circ}\right.$ $34^{\prime}$ W, elev. $\left.625 \mathrm{~m}\right)$. The area consists of gently undulating sandhills vegetated with sand sagebrush (Artemisia filifolia Torr.) and high-seral mixed prairie. The mean annual precipitation is $572 \mathrm{~mm}$, with about $70 \%$ occurring as rain during the April through September growing season. Mean monthly temperatures range from $1^{\circ} \mathrm{C}$ in January to $29^{\circ} \mathrm{C}$ in July (Unpublished data, Southern Plains Range Research Station). The area is lightly stocked with cow-calf and stocker herds at 22 AUD ha-1.
Grazing is initiated at the first of April and cattle are removed from the pastures in early September. Pastures are relatively large at 635 ha, but water is well-distributed throughout the study area, with most water sources within $3.2 \mathrm{~km}$ of another.

Data were collected on Deep Sand ecological sites with slopes of 1 to $12 \%$. The dominant soils were Pratt loamy fine sands (sandy, mixed, mesic Lamellic Haplustalfs) and were interspersed with Tivoli fine sands (mixed, thermic Typic Ustipsamments) on the tops of dunes (Nance et al. 1960). Sand sagebrush was the dominant woody plant, providing 20 to $50 \%$ canopy cover over most of the area. Other woody plants included sand plum (Prunus angustifolia Marsh.), which occurred in isolated thickets, and eastern redcedar (Juniperus virginiana L.), which was sparsely distributed throughout the pastures. The herbaceous component was dominated by little bluestem [Schizachyrium scoparium (Michx.) Nash], gramas (Bouteloua spp. Lag.), western ragweed (Ambrosia psilostachya D.C.), sand bluestem (Andropogon hallii Hack.), sand lovegrass [Eragrostis trichodes (Nutt.) Wood], and Texas croton [Croton texensis (Kl.) Muell. Arg.].

\section{Methods}

We selected 16, 4-ha sites with similar vegetative composition and at least 1,600 $\mathrm{m}$ distance from each other and permanent water sources. Each site was randomly assigned a fall or spring fire treatment so that 4 sites were burned in each season for each of 2 years. Fall burns were conducted on 16 November 1999 or 14 November 2000 , when most warm-season plants were dormant. Spring burns were applied 17 April 2000 or 12 April 2001, when warm-season plants had just initiated growth and sand sagebrush leaves were about $3 \mathrm{~cm}$ long. Burned sites represented less than $2 \%$ of each pasture and were exposed to grazing by cattle from early April to September. Burn treatments were blocked within pastures so each cattle herd had equal access to a fall- and springburned plot. A cattle exclosure, measuring $5 \times 10 \mathrm{~m}$ and constructed of wire panels with $10-\mathrm{cm}$ mesh, was erected near the center of each burned plot and on 8 nonburned sites with similar vegetation located 1,600 $\mathrm{m}$ from water and burned patches. Each exclosure was paired with an adjacent plot open to grazing so forage utilization could be estimated by differences in end-of-season grass standing crop.
End-of-season herbage standing crop was estimated for the first growing season after treatments by clipping in September. The sampling scheme consisted of a 100 $\mathrm{m}$ pace transect placed in the center of each burned plot and 50, 100, 200, 400, and $800 \mathrm{~m}$ from the edge of burns. Distances from burned plots were determined by following a compass and using a Yardage Pro 800 laser range finder (Bushnell Sports Optics, Overland Park, Kans.). Direction was determined by restrictions to similar soils and the ability to travel the $800 \mathrm{~m}$ in a straight line without violating the pasture boundary. At each distance, a 100-m transect, perpendicular to the line of travel, was paced and vegetation was sampled every $10 \mathrm{~m}$. Points beneath dense sand sagebrush canopy and inaccessible to cattle were not sampled. All forbs and grasses were clipped to ground level in $0.1 \mathrm{~m}^{2}$ quadrats and bagged separately to determine grass, forb, and total herbage standing crop. Standing crop between 50 and $800 \mathrm{~m}$ from burns was assumed to reflect the distribution of grazing use. Standing crop estimates were also determined from 10 quadrats within each of the cattle exclosures and their paired plots. Data from exclosures and grazed plots $1,600 \mathrm{~m}$ from burns were used only for estimating utilization. Samples were air-dried to a constant weight at $53^{\circ} \mathrm{C}$ and weighed to the nearest $0.01 \mathrm{~g}$.

Forage utilization, grass, forb, and total herbage standing crop were analyzed as a split block design using general linear model analysis of variance (SAS Institute 1985). Utilization models included terms for block, burn, year and their interactions. Planned contrasts were performed for each of the herbage components to determine whether standing crop on burned plots differed from standing crop 50 to $800 \mathrm{~m}$ away from burns. The herbage components within burned plots were tested for differences by year, block, season of burn and their interactions. All other models included an additional term for distance from burned sites. Regression analysis was used to determine relationships between standing crop of herbage components and distance from burn. A 5\% significance level was used for all tests. When differences occurred and multiple comparisons were made, means were separated using Fisher's protected least significant difference (Steele and Torrie 1980). 


\section{Results and Discussion}

No significant interactions occurred in standing crop or utilization analyses $(P>$ 0.05 ). Grass and total herbage standing crop were about $40 \%$ lower in 2001 than they were in $2000(\mathrm{P}<0.01$, Fig. 1). Utilization across burn treatments was greater in 2001 than 2000 at 66 and $51 \%$, respectively $(P<0.01)$. Since forb standing crop was similar across years $(\mathrm{P}>$ 0.54 ), changes in total herbage were primarily caused by reduced grass yields. Stocking rates were the same each year, so the sharp reduction in grass standing crop can probably be explained by differences in precipitation and increased utilization was likely an effect of reduced forage availability. Although annual precipitation was near the 62-year mean during both years of the study, growing season precipitation was $10 \%$ below the long-term average in 2000 and $25 \%$ below the long-term average in 2001.

Utilization of fall-burned (76\%) and spring-burned plots $(80 \%)$ was similar ( $\mathrm{P}$ $>0.43$ ) as was end-of-season grass standing crop ( $P>0.74)$, with 373 and $356 \mathrm{~kg}$ ha-1, respectively (Fig. 2). Standing crop was similar between burn seasons for forbs $(P>0.24)$ and total herbage $(P>$ 0.23 ) as well. The seasonal timing of fire generally affects plant species composition (Towne and Owensby 1984), which could be expected to alter use by herbivores. However, plant communities differed only slightly by season of burn (Vermeire 2002). Unless the quantity of desirable forages is limited or foraging efficiency is reduced, forage quality will likely be the dominant factor in site selec-

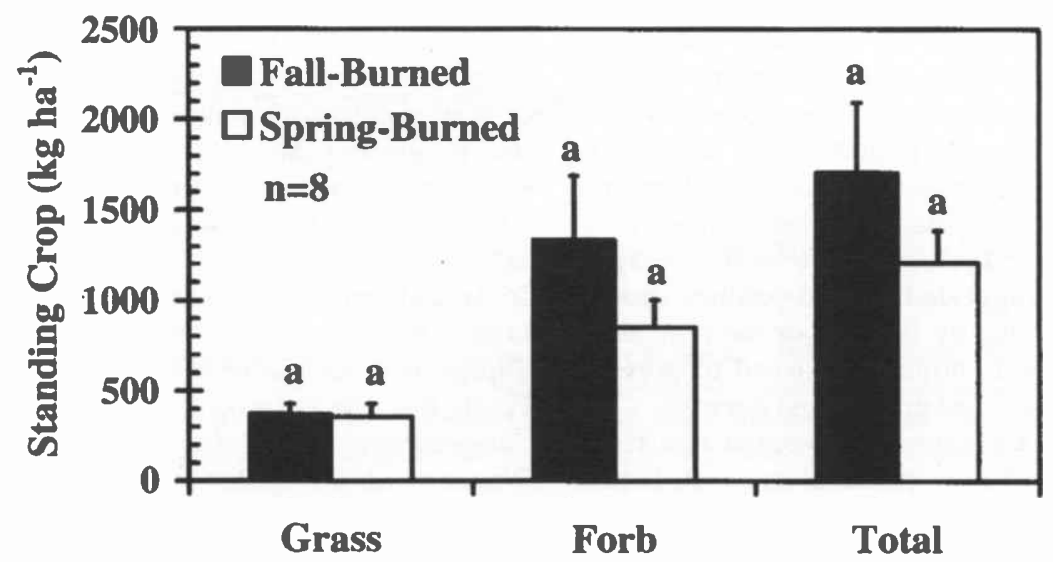

Fig. 2. Standing crop and standard errors of grasses, forbs, and total herbage across years for fall- and spring-burned plots. Means within herbage components with different letters are different $(\mathbf{P}<0.05)$. tion by large herbivores. Bison (Bison bison L.) preference among tallgrass prairie sites burned in spring, summer, or fall was found to be minor despite measurable changes in plant community composition (Coppedge and Shaw 1998).

Grass standing crop on burned plots was much lower than that across non-burned sites $(\mathrm{P}<0.01$, Fig. 3$)$. We visually estimated about $25 \%$ of the difference in standing crop could be attributed to standing dead material from previous years' growth, based on coloration. The $78 \%$ utilization of burned plots was much greater than the $19 \%$ utilization observed on nonburned plots $1,600 \mathrm{~m}$ away $(\mathrm{P}<0.01)$. Although fire effects on the level of forage utilization have not been quantified previously, greater use was expected on burned sites because forage production, quality, and accessibility are commonly increased by fire (Wright and Bailey 1982) and the

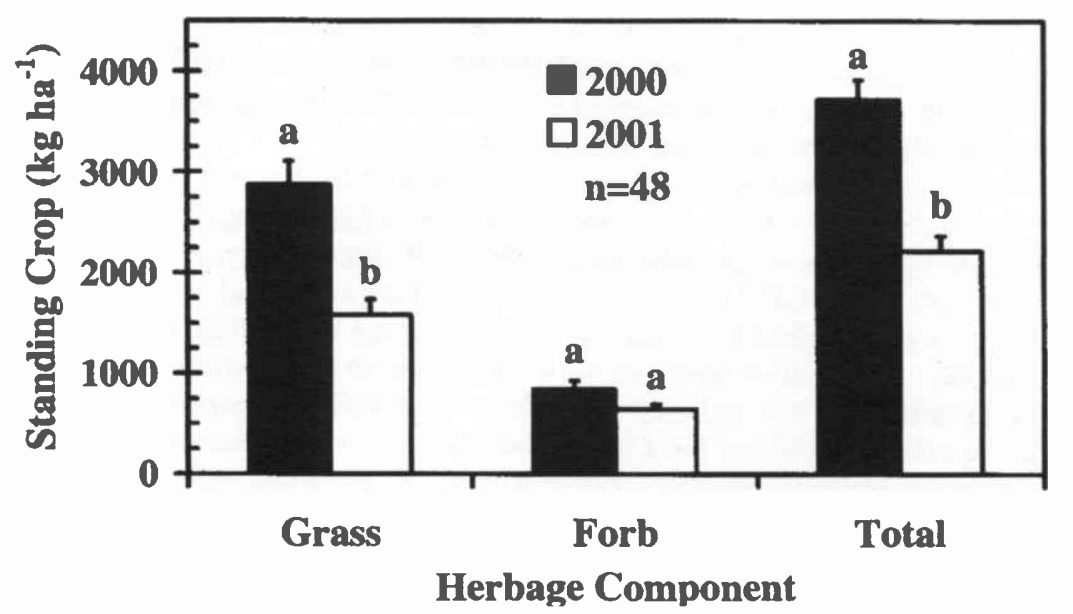

Fig. 1. Standing crop and standard error of grasses, forbs, and total herbage across burn season and distance treatments for 2000 and 2001. Means within herbage components with different letters are different $(\mathbf{P}<\mathbf{0 . 0 5})$. higher ratio of green versus senescent vegetation is believed to attract large herbivores (Stuth 1991, Mitchell and Villalobos 1999). Cattle were observed utilizing burned patches during their intensive morning and late afternoon feeding periods. Herds remained near water sources during the warmer periods of the day. Patch burning and the increased grazing pressure on burned plots promoted forb production $(P<0.01)$ and changed the sites from grass-dominated to forb-dominated communities. However, total standing crop was less than half of that on nonburned plots $(\mathrm{P}<0.01)$ despite the $60 \%$ increase of forbs on burned plots (Fig. 3).

A positive quadratic relationship existed between grass standing crop and distance from burned plots $(\mathrm{P}<0.01$ ), with $98 \%$ of the distance effect being explained by linear and quadratic terms (Fig. 4). Grass standing crop ranged from about $1,730 \mathrm{~kg}$ $\mathrm{ha}^{-1}$ at $50 \mathrm{~m}$ to $3,470 \mathrm{~kg} \mathrm{ha}^{-1}$ at $800 \mathrm{~m}$ from burns. The greatest reductions in standing crop occurred within $200 \mathrm{~m}$, with grass standing crop increasing by about $6 \mathrm{~kg} \mathrm{ha}^{-1}$ for each additional meter from the edge of burned patches. The increased forage use reported around dehydrated molasses was also focused within $200 \mathrm{~m}$ of the supplement, but utilization was relatively uniform in the area affected (Bailey and Welling 1999). The reduction in standing crop with distance from burned sites was less gradual than has been shown for forage use around water sources in gentle terrain (Valentine 1947, Herbel et al. 1967, Martin and Cable 1974). Water and fire differ as distribution tools in that water is required, whereas burned sites are simply preferred. Forage quality is similar across distances from water prior to grazinginduced changes and cattle can remain 


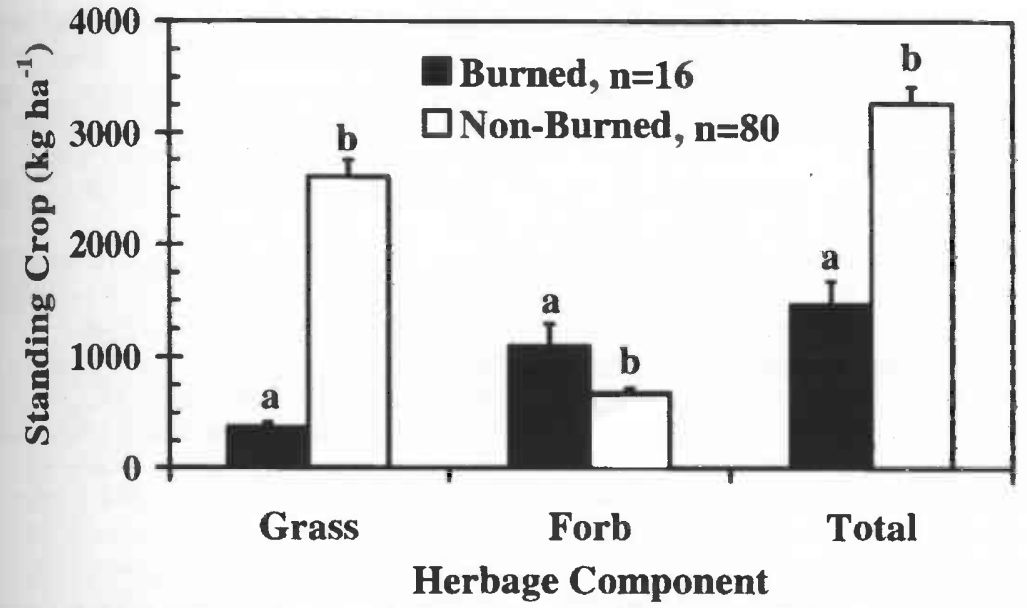

Fig. 3. Standing crop and standard error of grasses, forbs, and total herbage across years for burned sites and non-burned sites 50, 100, 200, 400, and $800 \mathrm{~m}$ from burns. Means within herbage components with different letters are different $(P<0.05)$.

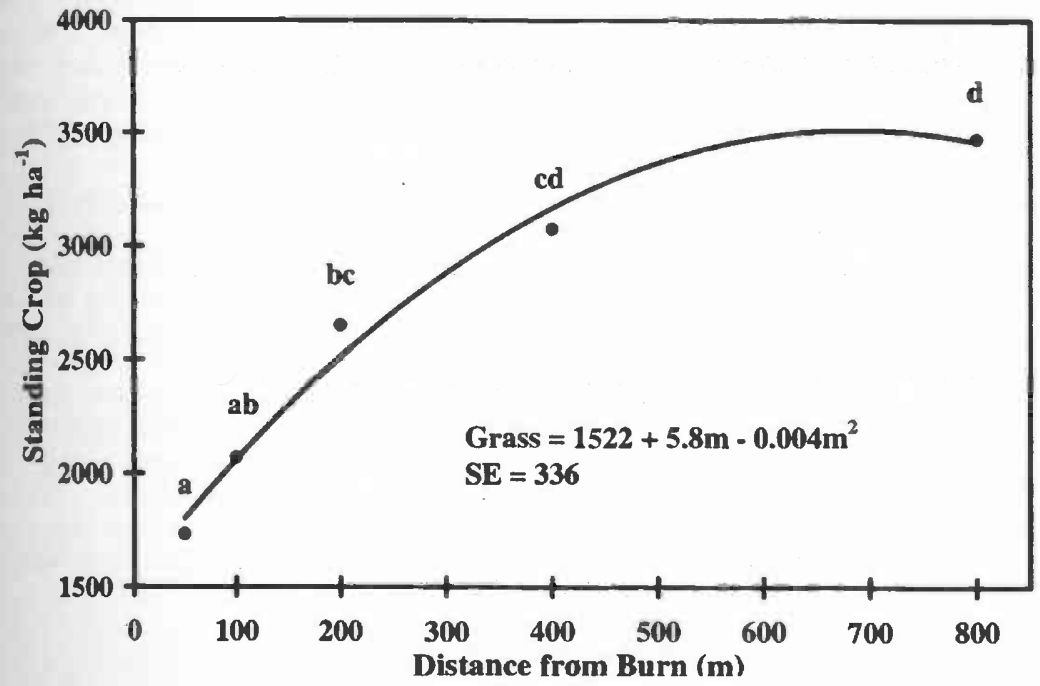

Fig. 4. Relationship of grass standing crop with distance from burned patches across years and burn seasons. Distance means with different letters are different $(\mathbf{P}<0.05)$. with the growing-season drought of 2001 and the resulting increase in grazing pressure. Since forbs were unaffected by distance, the relationship between total herbage and distance from burns was similar to that of grass standing crop, differing only by the intercepts (Fig. 5). Linear and quadratic terms explained $98 \%$ of the distance effect for total herbage.

\section{Management Implications}

Prescribed fire is among the most powerful grazing distribution tools available. We found cattle were willing to travel at least $1,600 \mathrm{~m}$ from water to utilize burned patches during their intensive feeding periods. Since cattle showed no preference between sites burned in spring or fall, burn season could be selected to address other management goals with little or no effect on grazing use by cattle. Additionally, utilization of surrounding non-burned vegetation increased in a predictable manner with proximity to burned patches. These results indicate that grazing distribution can be controlled with some precision using prescribed fire. Burned patches could be strategically placed to attract cattle to underutilized portions of pastures, or to draw them away from sensitive areas, such as riparian zones. Fuhlendorf and Engle (2001) proposed that patch burning could also be used to increase heterogeneity across the landscape. The change from grass-dominated to forb-dominated communities on burned patches supported this hypothesis. Such changes in vegetative composition were limited to burned sites and would be expected to be short-lived, particularly if burned sites were traditionally near water as long as the forage supply is adequate. However, cattle must leave burned sites multiple times during the day unless water is available nearby. Given the contrast in forage quality on burned and non-burned sites and that water was located $1,600 \mathrm{~m}$ from the burns, there was little incentive for cattle to spend much time grazing non-burned vegetation surrounding burned sites.

Forb standing crop was similar across distances from burned plots at $674 \mathrm{~kg} \mathrm{ha}^{-1}$ ( $\mathrm{P}>0.82$ ). Although grass standing crop was reduced with proximity to burns, the reductions were insufficient to promote a measurable forb response as was observed within burned plots. Higher stocking rates would have increased forage use, but probably would not have altered the rate of change in grass or forb standing crop with distance from burns. These relationships were similar between years even

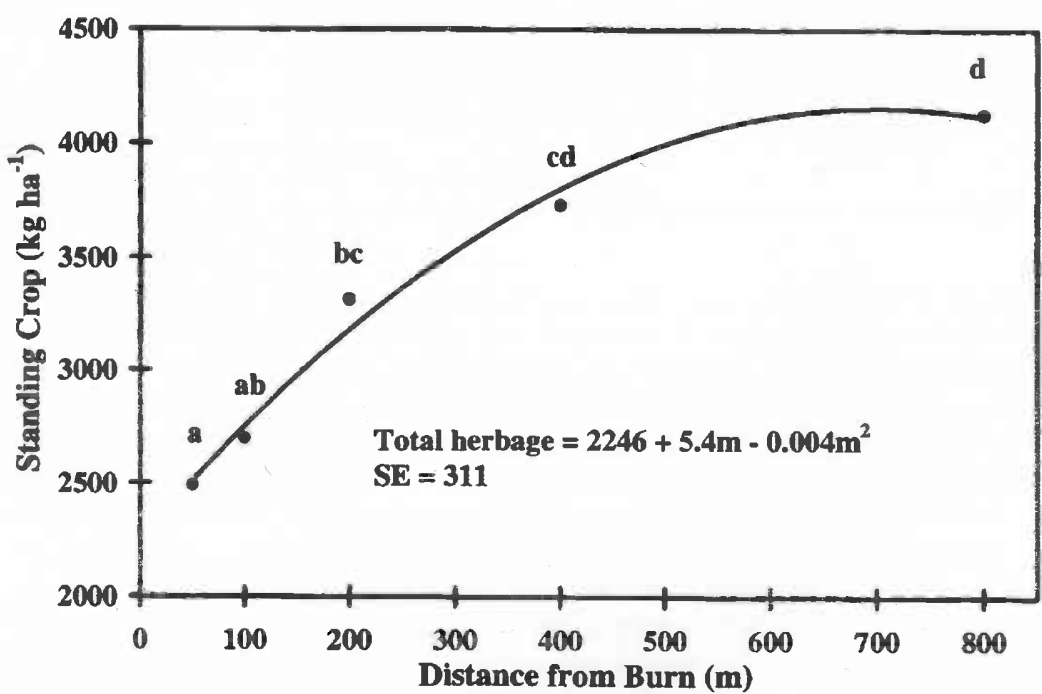

Fig. 5. Relationship of total herbage standing crop with distance from burned patches across years and burn seasons. Distance means with different letters are different $(\mathbf{P}<\mathbf{0 . 0 5})$. 
avoided by livestock. In tallgrass prairie, grasses regained dominance within 2 or 3 years after patches were burned and grazed by bison (Coppedge et al. 1998). Our results indicate that prescribed fire is a powerful attractant for cattle and that it may provide an inexpensive, non-permanent alternative for manipulating grazing distribution.

\section{Literature Cited}

Bailey, D. W. and R. Welling. 1999. Modification of cattle grazing distribution with dehydrated molasses supplement. J. Range Manage. 52:575-582.

Bailey, D. W., J. E. Gross, E. A. Laca, L. R. Rittenhouse, M. B. Coughenour, D. M. Swift, and P. L. Sims. 1996. Mechanisms that result in large herbivore grazing distribution patterns. J. Range Manage. 49:386-400.

Coppedge, B. R: and J. H. Shaw. 1998. Bison grazing patterns on seasonally burned tallgrass prairie. J. Range Manage. 51:258-264.

Coppedge, B. R., D. M Engle, C. S. Toepfer, and J. H. Shaw. 1998. Effects of seasonal fire, bison grazing, and climatic variation on tallgrass prairie vegetation. Plant Ecol. 139:235-246.

Fuhlendorf, S. D. and D. M. Engle. 2001. Restoring heterogeneity on rangelands: ecosystem management based on evolutionary grazing patterns. BioScience 51:625-632.
Herbel, C. H., F. N. Ares, and A. B. Nelson. 1967. Grazing distribution patterns of Hereford and Santa Gertrudis cattle on a southern New Mexico range. J. Range Manage. 20:296-298.

Hooper, J. F., J. P. Workman, J. B. Grumbles, and C. W. Cook. 1969. Improved livestock grazing distribution with fertilizer: a preliminary economic evaluation J. Range Manage. 22:108-1 10.

Martin, S. C. and D. R. Cable. 1974. Managing semidesert grass-shrub ranges USDA Tech. Bull. 1480. Washington, D.C.

Martin, S. C. and D. E. Ward. 1970. Rotating access to water to improve semidesert cattle range near water. J. Range Manage 23:22-26.

Martin, S. C. and D. E. Ward. 1973. Salt and meal-salt help distribute cattle use on semidesert range. J. Range Manage. 26:94-97.

McIlvain, E. H. and M. C. Shoop. 1971. Shade for improving cattle gains and rangeland use. J. Range Manage. 24:181-184.

Mitchell, R. B. and C. Villalobos. 1999. Do cattle prefer burned or non-burned Bothriochloa ischaemum?, p. 450-451. In: Proc. $6^{\text {th }}$ International Rangeland Congress, People and Rangelands - Building the Future vol. 1. International Rangeland Congress.

Nance, E. C., C. A. Steers, E. L. Cole, M. L. Miller, and C. F. Fanning. 1960. Soil survey Woodward County, Oklahoma. USDA, Washington, D.C.
Samuel, M. J., F. Rauzi, and R. H. Hart. 1980. Nitrogen fertilization of range: yield, protein content, and cattle behavior. J. Range Manage. 33:1 19-121.

SAS Institute. 1985. SAS/STAT Guide for personal computers, Version 6 edition. Cary, N.C.

Steele, R. G. D. and J. H. Torrie. 1980. Principles and procedures of statistics. McGraw-Hill Book Co., New York.

Stuth, J. W. 1991. Foraging Behavior, p. 65-83. In: R. K. Heitschmidt and J. W. Stuth (eds.) Grazing Management: An Ecological Perspective. Timber Press, Portland, Ore.

Towne, G. and C. Owensby. 1984. Long-term effects of annual burning at different dates in ungrazed Kansas tallgrass prairie. J. Range Manage. 37:392-397.

Valentine, K. A. 1947. Distance from water as a factor in grazing capacity of rangeland. $\mathrm{J}$. For. 45:749-754.

Vallentine, J. F. 1990. Grazing management. Academic Press, Inc., San Diego, Calif.

Vermeire, L. T. 2002. The fire ecology of sand sagebrush-mixesd prairie in the Southern Great Plains. Ph.D. Diss., Texas Tech Univ. Lubbock, Tex.

Wright, H. A. 1974. Range burning. J. Range Manage. 27:5-11.

Wright, H. A. and A. W. Bailey. 1982. Fire Ecology: United States and Southern Canada.John Wiley \& Sons, New York, N.Y. 